\title{
E5564 inhibits immunosuppressive cytokine IL-10 induction promoted by HIV-1 Tat protein
}

Elmostafa Bahraoui ${ }^{1,2,3}$, Laurence Briant $^{4}$ and Nathalie Chazal ${ }^{4^{*}}$

\begin{abstract}
Background: In HIV-1 infected patients, production of interleukin-10 (IL-10), a highly immunosuppressive cytokine, is associated with progression of infection toward AIDS. HIV-1 Tat protein, by interacting with TLR4-MD2 at the membrane level, induces IL-10 production by primary human monocytes and macrophages. In the present study we evaluated the effect of the TLR4 antagonist Eritoran tetrasodium (E5564) on HIV-1 Tat-induced IL-10 production.

Findings: Here, we confirm that the recombinant HIV-1 Tat protein and the GST-Tat 1-45 fusion protein efficiently stimulate IL-10 production by primary monocytes and macrophages and that this stimulation is inhibited by blocking anti-TLR4 mAbs. We show that a similar inhibition is observed by preincubating the cells with the TLR4 antagonist E5564.
\end{abstract}

Conclusion: This study provides compelling data showing for the first time that the TLR4 antagonist E5564 inhibits the immunosuppressive cytokine IL-10 production by primary human monocytes and macrophages incubated in the presence of HIV-1 Tat protein.

Keywords: Tat, Monocyte, Macrophage, TLR4, IL-10, E5564

\section{Introduction}

In HIV-1 infected patients, the deregulation of the immune system precedes the decline of the $\mathrm{T} \mathrm{CD} 4^{+}$lymphocytes population. This immune disorder is mainly associated with the loss of T-cell proliferation in response to stimulating antigens and with a shift from Th1 to Th2 cytokines profile, leading to high levels of circulating TNF- $\alpha$, IL-1, IL-4, IL-6, IL-12. This deregulation is accompanied by an enhanced secretion of IL-10 [1-5], an immunosuppressive cytokine crucial for the global immune dysfunction occurring during the course of HIV-1 infection [6]. Indeed, peripheral blood mononuclear cells (PBMCs) from HIV1-positive patients produce high levels of IL-10, whose level increases as the patient progresses toward AIDS.

In addition to its role in viral gene expression, the HIV-1 Tat transactivating protein plays a key role in the dysregulation of the host immune system. Tat is secreted by infected cells and detected at the nM level in the serum of HIV-1 positive patients [7-9]. This cell-free

\footnotetext{
* Correspondence: nathalie.chazal@cpbs.cnrs.fr

${ }^{4}$ Centre d'études d'agents Pathogènes et Biotechnologies pour la Santé (CPBS), UMR5236, CNRS - Université Montpellier 1-Montpellier 2, Montpellier, France

Full list of author information is available at the end of the article
}

protein exerts bystander effects on other cells whether or not they are infected, leading to the modulation of cellular genes expression. In this field, HIV-1 Tat, by acting at the cell membrane surface, stimulates IL-10 and TNF- $\alpha$ secretion by human monocytes and macrophages $[10,11]$. Different domains in the HIV-1 Tat protein have been implicated in interactions with various cell receptors: (1) the N-terminal region in Tat binds the CD26 receptor expressed at the lymphocyte cell membrane; (2) the tripeptide RGD (Arginine-Glycine-Aspartate) motif interacts with $\alpha_{\mathrm{v}} \beta_{3}$ and $\alpha_{5} \beta_{1}$ integrins at the surface of dendritic cells; (3) the basic region recruits membrane lipids and the VEGF receptor expressed by endothelial cells [12]; (4), Albini et al. reported the interaction of the cysteine-rich region in Tat (24-51) with CCR2, CCR3 and CXCR4 chemokines receptors [13]. Due to this last property, Tat was proposed to compete with infection by X4-tropic HIV strains; (5). More recently, we reported that Tat N-terminal domain, by interacting with the Toll-like receptor 4-myeloid differentiation factor 2 complexes (TLR4-MD2), promotes TNF- $\alpha$ and IL-10 secretion by macrophages and monocytes [14]. Given the crucial importance of IL-10 in immune dysfunction and the capacity of IL-10 to synergize with inflammatory cytokines to 
enhance viral replication in HIV-1-positive patients, inhibition of Tat/TLR4-MD2 may represent in the long term an attractive therapeutic strategy.

TLR4 antagonists include molecules such as Eritoran tetrasodium (E5564) and its predecessors (E5531) [15], Resatorvid (TAK 242, a small molecule inhibitor of TLR4CD14 mediated intracellular signaling), and antibodies targeting the TLR4 receptor. Of note, some therapeutic agents such as ketamine, opioids and statins may also non-selectively interfere with TLR4 [16-18]. E5564 is a structural analog of the A lipid from $R$ sphaeroides (RsLA), originally synthesized at the Eisai Research Institute of Boston (Andover, MA) [19]. E5564 competitively binds to TLR4-MD2, prevents LPS-induced NF- $\mathrm{KB}$ activation, inhibits TNF- $\alpha$, IL-1 $\beta$, IL- 6 and IL-10 release in vitro and in vivo, and abolishes inflammatory responses in animal and human models of endotoxemia [15] without significant intrinsic agonistic effects.

According to these properties, the present study was designed to evaluate the capacity of E5564 to inhibit Tat-induced IL-10 production by human monocytes and macrophages. First, we determined the optimal monocytes culture conditions required for inhibition of LPS-induced secretion of IL-10 by E5564. PBMCs were isolated from buffy coats from HIV-negative donors by Ficoll density gradient centrifugation (Pharmacia). The cells were resuspended in 60/30 complete medium (60\% AIM V and $30 \%$ Iscove (Gibco) containing penicillin $(100 \mathrm{IU} / \mathrm{ml})$, streptomycin $(100 \mu \mathrm{g} / \mathrm{ml})$ and $10 \%$ FCS and cultured for $24 \mathrm{~h}$ at $37^{\circ} \mathrm{C}$ in $5 \% \mathrm{CO}_{2}\left(10^{6}\right.$ cells/well $)$ in 24 -well Primaria (Becton Dickinson) tissue culture plates for 24 hours at $37^{\circ} \mathrm{C}$ in $5 \% \mathrm{CO}_{2}$ in order to separate monocytes by plastic adherence. Non-adherent cells were removed, the remaining cells were washed twice and then stimulated by increasing concentrations of LPS either directly or after preincubation with $1 \mu \mathrm{g} / \mathrm{ml} \mathrm{HTA} 125$ anti-TLR4 blocking monoclonal antibody (mAb) (eBioscience), or with $10 \mathrm{nM}$ placebo or with $10 \mathrm{nM}$ E5564 (placebo and E5564 were kindly provided by Eisai Research Institute of Boston). Used at these concentrations E5564 and placebo displayed no cytotoxic effect (data not shown) [20]. After $24 \mathrm{~h}$ in culture, supernatants were collected and analyzed for human IL-10 content (ELISA kit, BD Biosciences). In our hands, $10 \mathrm{nM}$ E5564 were effective at reducing IL-10 production to background levels following stimulation with 1 to $2 \mathrm{ng} / \mathrm{ml}$ LPS. No inhibition was observed when LPS stimulation was performed in the presence of placebo (Figure 1). Notably, this inhibition was more efficiently achieved using the E5564 molecule than the anti-TLR4 mAbs.

Next, we determined in vitro effects of the HIV-1 Tat protein on IL-10 production by human monocytes.

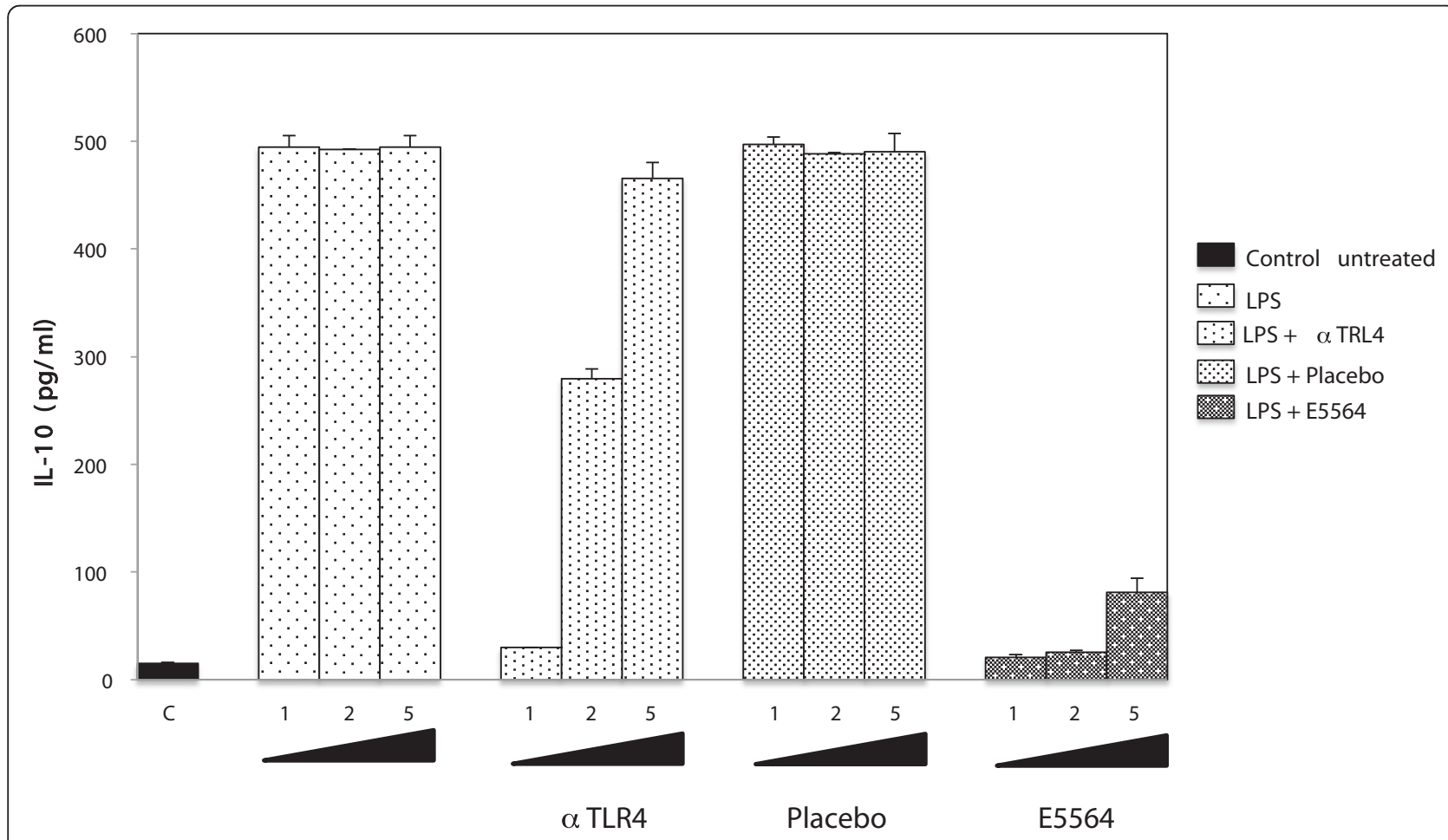

Figure 1 E5564 inhibits LPS-induced production of IL-10 by primary human monocytes. Primary human monocytes were treated or not by anti-TLR4 blocking antibodies $(1 \mathrm{\mu g} / \mathrm{ml})$, or with placebo $(10 \mathrm{nM})$ or with E5564 $(10 \mathrm{nM})$ before stimulation by increasing concentration of LPS $(1,2,5 \mathrm{ng} / \mathrm{ml})$. The data represent means concentrations of IL-10 in culture supernatants \pm SD of three independent experiments. 

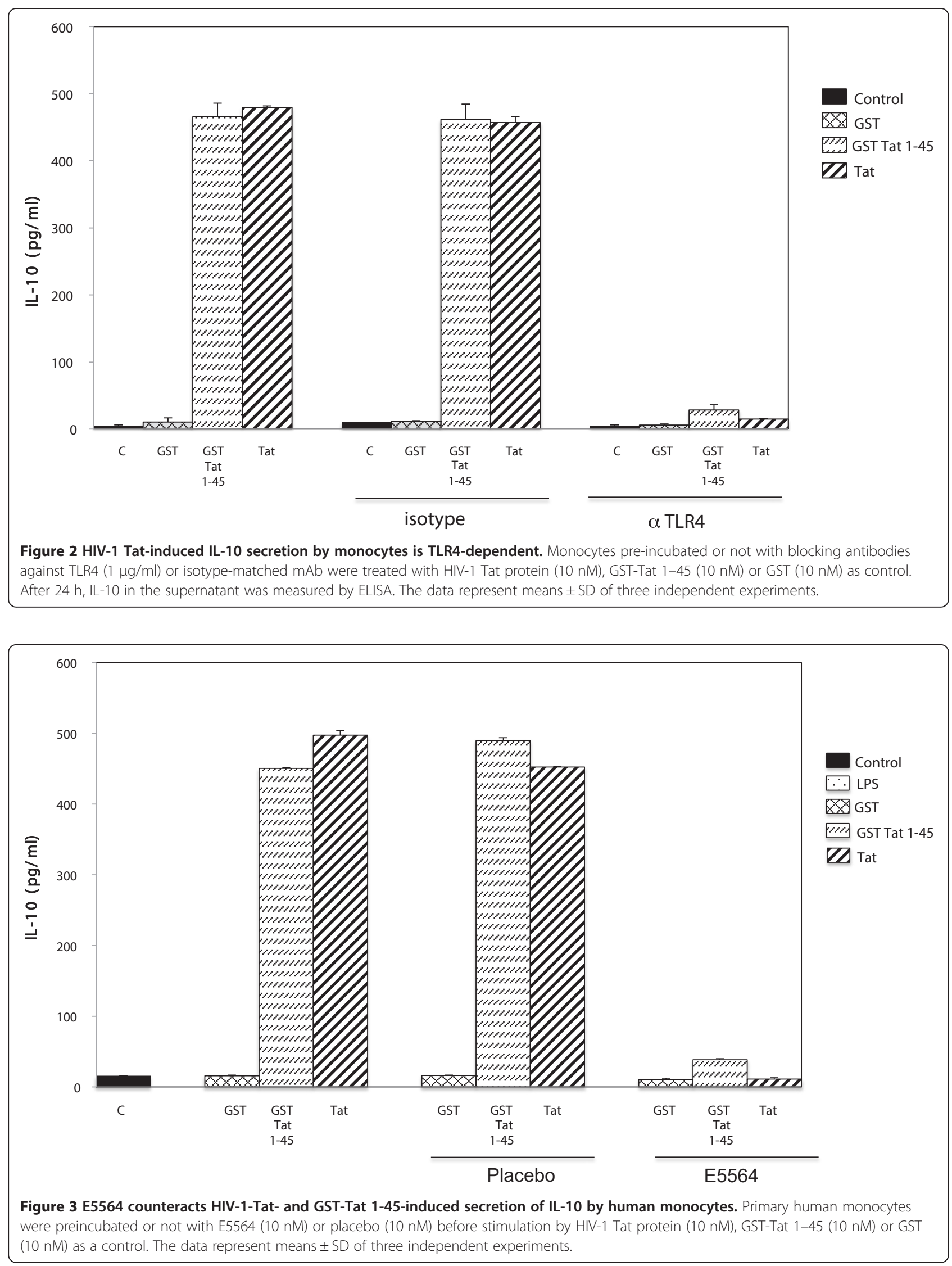
Recombinant HIV-1 Tat protein 1-86 (obtained from the Agence Nationale de la Recherche sur le SIDA, Paris, France) or recombinant GST-Tat 1-45 produced from our laboratory as previously described [21] and controlled for endotoxin contamination using the Limulus amebocyte lysate (LAL) assay (Bio-Sepra, France) [10,21-23] were added to primary human monocytes pre-incubated or not of with the HTA125 anti-TLR4 mAb or with a nonspecific isotype-matched IgG $(1 \mu \mathrm{g} / \mathrm{ml})$. The supernatant was collected $24 \mathrm{~h}$ post-stimulation and analyzed for human IL-10 content as previously described [21]. Using this approach, we showed that stimulation with recombinant Tat protein or recombinant GST-Tat 1-45 equally stimulated IL-10 production (Figure 2). In contrast, we found that anti-TLR4 antibodies dramatically decreased both Tat and GST-Tat 1-45-induced cytokine release. No inhibition was observed when Tat or GST Tat-145 stimulation was performed in the presence of irrelevant isotype $\mathrm{mAb}$ (Figure 2).
We next evaluated the consequences of E5564 treatment on IL-10 production by monocytes stimulated with recombinant Tat or GST-Tat $1-45$. We found that 10 $\mathrm{nM}$ of E5564 were effective at counteracting the stimulating effects of recombinant Tat or recombinant GSTTat 1-45. This effect was not observed when the cells were incubated with the same concentration of placebo (Figure 3). According to this observation, E5564 was effective at inhibiting Tat-induced IL-10 secretion by monocytes. Finally, these experiments were repeated using primary human macrophages as target cells. Monocytes prepared from PBMCs by plastic adhesion were differentiated into macrophages by incubation in a $10 \%$ FCS, $1 \%$ M-CSF and 1\% PS mixture. Blood monocytes adhered to plastic after $1 \mathrm{~h}$ and acquired macrophage-like morphology within 5 days. On day 7 , differentiated macrophages were stimulated with the recombinant HIV-1 Tat protein in presence of anti-TLR4 mAb, or irrevelant isotype $\mathrm{mAb}$, or placebo or E5564. In these conditions E5564

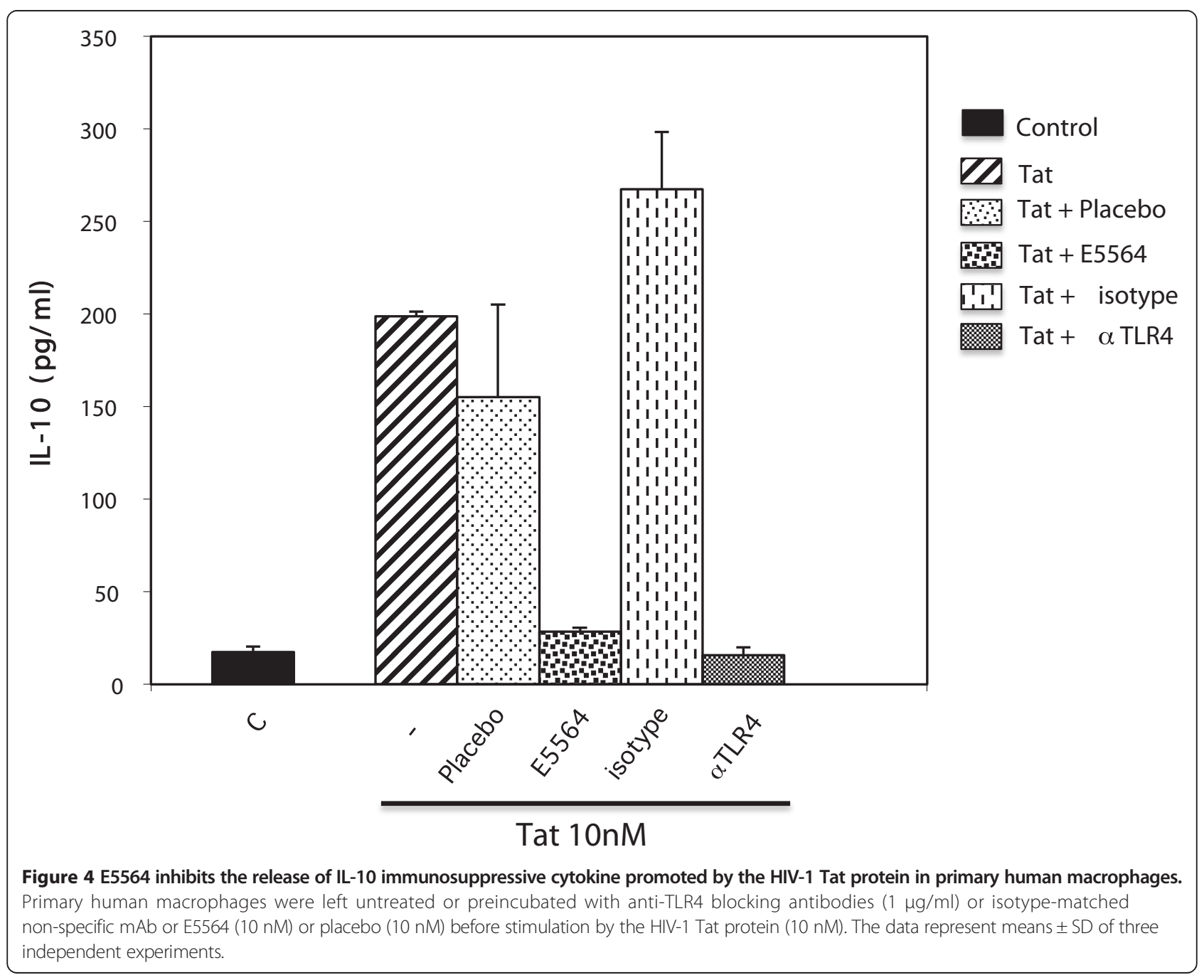


and anti-TLR4 mAb inhibited Tat-induced cytokine production. No inhibition was observed when macrophages were incubated with the placebo molecule or with the isotype-matched non-specific mAb (Figure 4).

Altogether, these results indicate that the TLR4 agonist E5564 inhibits Tat-induced secretion of IL-10, by primary human monocytes and macrophages. This molecule was recently shown to represent a novel issue in therapeutic management of inflammation associated with influenza infection [24-26] and treatment for sepsis [27]. The powerful immunosuppressive properties of IL-10, the strong association between elevated serum concentrations of this immunosuppressive Th2 cytokine with disease progression in HIV-1-infected patients together with the capacity of the retroviral Tat protein to stimulate IL-10 release through TLR4 binding strongly supports that inhibition of Tat/TLR4-MD2 interactions may represent a good candidate to decrypt the mechanisms responsible for IL-10 deregulation in HIV infection. In this respect, E5564 represents an attractive tool for understanding how HIV infection induces a state of immunodeficiency.

\section{Statistical tests}

All statistical analyses used the Student's t-test, unpaired for normal distribution, for at least three independent experiments. Differences were considered significant at $\mathrm{p}$ values $<0.05$. Microsoft Excel and Prism were used to construct the plots and measure means, standard deviations and $\mathrm{p}$ values.

\section{Abbreviations}

PBMCs: Peripheral blood mononuclear cells; L-10: interleukin-10; TLR-4: Toll-like receptor 4; LPS: Lipopolysaccharide; E5564: Eritoran tetrasodium;

GST: Glutathione S-transferase.

\section{Competing interests}

The authors declare that they have no competing interests.

\section{Authors' contributions}

NC conceived the study and analyzed the data. NC performed the laboratory work. EB, LB and NC wrote the manuscript. All authors read and approved the final manuscript.

\section{Acknowledgements}

This work was supported by Agence Nationale de la Recherche sur le SIDA (ANRS). We are grateful to Eisai Research Institute of Boston (Andover, MA) to provide us E5564.

\section{Author details \\ 'Université Paul Sabatier, EA 3038, 118 Route de Narbonne, 31062 Toulouse, France. ${ }^{2}$ INSERM, U1043, CPTP, CHU Purpan, BP302831024 Toulouse, Cedex 3, France. ${ }^{3}$ CNRS, U5282, CPTP, CHU Purpan, BP302831024 Toulouse, Cedex3, France. ${ }^{4}$ Centre d'études d'agents Pathogènes et Biotechnologies pour la Santé (CPBS), UMR5236, CNRS - Université Montpellier 1-Montpellier 2, Montpellier, France.}

Received: 15 July 2014 Accepted: 24 November 2014 Published online: 04 December 2014

\section{References}

1. Clerici $M$, Shearer GM: A TH1->TH2 switch is a critical step in the etiology of HIV infection. Immunol Today 1993, 14:107-111.
2. Clerici M, Sarin A, Coffman RL, Wynn TA, Blatt SP, Hendrix CW, Wolf SF, Shearer GM, Henkart PA: Type 1/type 2 cytokine modulation of T-cell programmed cell death as a model for human immunodeficiency virus pathogenesis. Proc Natl Acad Sci U S A 1994, 91:11811-11815.

3. Emilie D, Fior R, Llorente L, Marfaing-Koka A, Peuchmaur M, Devergne O, Jarrousse B, Wijdenes J, Boue F, Galanaud P: Cytokines from lymphoid organs of HIV-infected patients: production and role in the immune disequilibrium of the disease and in the development of $B$ lymphomas. Immunol Rev 1994, 140:5-34.

4. Graziosi C, Pantaleo G, Fauci AS: Comparative analysis of constitutive cytokine expression in peripheral blood and lymph nodes of HIV-infected individuals. Res Immunol 1994, 145:602-605. discussion 605-607.

5. Alfano M, Poli G: The cytokine network in HIV infection. Curr Mol Med 2002, 2:677-689.

6. Clerici M, Wynn TA, Berzofsky JA, Blatt SP, Hendrix CW, Sher A, Coffman RL, Shearer GM: Role of interleukin-10 in Thelper cell dysfunction in asymptomatic individuals infected with the human immunodeficiency virus. J Clin Invest 1994, 93:768-775.

7. Goldstein G: HIV-1 Tat protein as a potential AIDS vaccine. Nat Med 1996, 2:960-964.

8. Westendorp MO, Shatrov VA, Schulze-Osthoff K, Frank R, Kraft M, Los M, Krammer PH, Droge W, Lehmann V: HIV-1 Tat potentiates TNF-induced NF-kappa B activation and cytotoxicity by altering the cellular redox state. The EMBO journal 1995, 14:546-554.

9. Xiao H, Neuveut C, Tiffany HL, Benkirane M, Rich EA, Murphy PM, Jeang KT: Selective CXCR4 antagonism by Tat: implications for in vivo expansion of coreceptor use by HIV-1. Proc Natl Acad Sci U S A 2000, 97:11466-11471.

10. Bennasser Y, Badou A, Tkaczuk J, Bahraoui E: Signaling pathways triggered by HIV-1 Tat in human monocytes to induce TNF-alpha. Virology 2002, 303:174-180.

11. Leghmari K, Contreras X, Moureau C, Bahraoui E: HIV-1 Tat protein induces TNF-alpha and IL-10 production by human macrophages: differential implication of PKC-betall and -delta isozymes and MAP kinases ERK1/2 and p38. Cell Immunol 2008, 254:46-55.

12. Rubartelli A, Poggi A, Sitia R, Zocchi MR: HIV-I Tat: a polypeptide for all seasons. Immunol Today 1998, 19:543-545.

13. Albini A, Ferrini S, Benelli R, Sforzini S, Giunciuglio D, Aluigi MG, Proudfoot AE, Alouani S, Wells TN, Mariani G, Rabin RL, Farber JM, Noonan DM: HIV-1 Tat protein mimicry of chemokines. Proc Natl Acad Sci U S A 1998, 95:13153-13158.

14. Ben Haij N, Leghmari K, Planes R, Thieblemont N, Bahraoui E: HIV-1 Tat protein binds to TLR4-MD2 and signals to induce TNF-alpha and IL-10. Retrovirology 2013, 10:123.

15. Mullarkey M, Rose JR, Bristol J, Kawata T, Kimura A, Kobayashi S, Przetak M, Chow J, Gusovsky F, Christ WJ, Rossignol DP: Inhibition of endotoxin response by e5564, a novel Toll-like receptor 4-directed endotoxin antagonist. J Pharmacol Exp Ther 2003, 304:1093-1102.

16. Wittebole X, Castanares-Zapatero D, Laterre PF: Toll-like receptor 4 modulation as a strategy to treat sepsis. Mediat Inflamm 2010, 2010:568396.

17. Rice TW, Wheeler AP, Bernard GR, Vincent IL, Angus DC, Aikawa N, Demeyer I, Sainati S, Amlot N, Cao C, li M, Matsuda H, Mouri K, Cohen J: A randomized, double-blind, placebo-controlled trial of TAK-242 for the treatment of severe sepsis. Crit Care Med 2010, 38:1685-1694.

18. Roger T, Froidevaux C, Le Roy D, Reymond MK, Chanson AL, Mauri D, Burns K, Riederer BM, Akira S, Calandra T: Protection from lethal gram-negative bacterial sepsis by targeting Toll-like receptor 4. Proc Natl Acad Sci U S A 2009, 106:2348-2352.

19. Hawkins LD, Christ WJ, Rossignol DP: Inhibition of endotoxin response by synthetic TLR4 antagonists. Curr Top Med Chem 2004, 4:1147-1171.

20. Menghini R, Campia U, Tesauro M, Marino A, Rovella V, Rodia G, Schinzari F, Tolusso B, di Daniele N, Federici M, Zoli A, Ferraccioli G, Cardillo C: Toll-Like Receptor 4 Mediates Endothelial Cell Activation Through NF-kappaB but Is Not Associated with Endothelial Dysfunction in Patients with Rheumatoid Arthritis. PLoS One 2014, 9:e99053.

21. Badou A, Bennasser Y, Moreau M, Leclerc C, Benkirane M, Bahraoui E: Tat protein of human immunodeficiency virus type 1 induces interleukin-10 in human peripheral blood monocytes: implication of protein kinase C-dependent pathway. J Virol 2000, 74:10551-10562.

22. Bennasser $Y$, Bahraoui E: HIV-1 Tat protein induces interleukin-10 in human peripheral blood monocytes: involvement of protein kinase C-betall and -delta. FASEB J 2002, 16:546-554. 
23. Contreras X, Bennasser Y, Bahraoui E: IL-10 production induced by HIV-1 Tat stimulation of human monocytes is dependent on the activation of PKC beta(II) and delta isozymes. Microbes and infection/Institut Pasteur 2004, 6:1182-1190

24. Rallabhandi P, Phillips RL, Boukhvalova MS, Pletneva LM, Shirey KA, Gioannini TL, Weiss JP, Chow JC, Hawkins LD, Vogel SN, Blanco JC: Respiratory syncytial virus fusion protein-induced toll-like receptor 4 (TLR4) signaling is inhibited by the TLR4 antagonists Rhodobacter sphaeroides lipopolysaccharide and eritoran (E5564) and requires direct interaction with MD-2. mBio 2012, 3(4). doi: 10.1128/mBio.00218-12.

25. Neal MD, Jia H, Eyer B, Good M, Guerriero CJ, Sodhi CP, Afrazi A, Prindle T Jr, Ma C, Branca M, Ozolek J, Brodsky JL, Wipf P, Hackam DJ: Discovery and validation of a new class of small molecule Toll-like receptor 4 (TLR4) inhibitors. PLoS One 2013, 8:e65779.

26. Shirey KA, Lai W, Scott AJ, Lipsky M, Mistry P, Pletneva LM, Karp CL, McAlees J, Gioannini TL, Weiss J, Chen WH, Ernst RK, Rossignol DP, Gusovsky F, Blanco JC, Vogel SN: The TLR4 antagonist Eritoran protects mice from lethal influenza infection. Nature 2013, 497:498-502.

27. Barochia A, Solomon S, Cui X, Natanson C, Eichacker PQ: Eritoran tetrasodium (E5564) treatment for sepsis: review of preclinical and clinical studies. Expert Opin Drug Metab Toxicol 2011, 7:479-494.

doi:10.1186/s12985-014-0214-z

Cite this article as: Bahraoui et al.: E5564 inhibits immunosuppressive cytokine IL-10 induction promoted by HIV-1 Tat protein. Virology Journal 2014 11:214.

\section{Submit your next manuscript to BioMed Central and take full advantage of:}

- Convenient online submission

- Thorough peer review

- No space constraints or color figure charges

- Immediate publication on acceptance

- Inclusion in PubMed, CAS, Scopus and Google Scholar

- Research which is freely available for redistribution 